\title{
The Factors which Keep from Innovation Development (On the Example of the Tatarstan Republic)
}

\author{
Safiullina A.M. \\ Ivanov M.E. \\ Beloborodova M.A.
}

Kazan (Volga region) Federal University, 18, Kremlyovskaya Street, Kazan, Repablic of Tatarstan, Russian Federation, 420008

\section{Doi:10.5901/mjss.2014.v5n18p207}

\begin{abstract}
The article describes different factors which keep the region from innovation and technology development on the example of the Tatarstan Republic. When all the word is implementing innovation, there are still some reasons which prevent developing and making innovation climate as favorable as it possible. The key reasons are that the most enterprises don't take seriously the importance of the innovation and could hardly find a place for it in their strategies, lack of government support and the lack of financial support of innovation projects.
\end{abstract}

Keywords: innovation development, innovation activity, new technology, growth of the enterprise, high level of income, modernization.

\section{Introduction}

The main reason for insufficiently active innovation behavior of the business sector is that so far business models bring success to many companies in the Russian market, in particular those operating mostly in the domestic market. The innovation model will be demanded after renovation of the production base in industry and services is completed. And the second reason is relatively low level of rivalry in the local and regional markets on which most companies are operating.

As for the competition and structure of the markets, the innovation investigation shows that between the innovation active and passive organizations oriented mostly to the local and regional markets, protected from competition with large distances, transportation expenditures and administration barriers is twice as low among the innovation- active organizations than among the technologically passive organizations: $39.5 \%$ compared to $72.2 \%$.Regionalization of markets inhibits essentially the innovation activity of both large and small companies and the share of innovation-active companies among the organizations operating in the regional markets is $50-60 \%$ lower in the group of the largest companies and so large companies alike.

No matter whether the organizations implement or not innovatons their main difficulties are lack of money, high cost of innovations, lack of government support and economic risks related to innovations [6].

It is noteworthy that such factors as demand, infrastructure, problems with the intellectual property and cooperation are seldom considered by businessman as important or decisive although many measures of the present-day federal innovation policy oriented to these very barriers $[1,10,13,14]$.

\section{Theory}

In the Soviet time each industry ministry had special research institutions servicing the industry or sub-industry or a group of enterprises, but not individual organization. In the transitional period many enterprises stopped using services of industry research institutions for various reasons: a) low competitiveness of technological developments made by industry organizations compared to the foreign analogs available in the market; b) wide "pirate" use of the intellectual property of research organizations by private enterprises; c) insufficiency of funds at enterprises for support of long-term projects. As a result, the system of supply and demand for the results of R\&D in different industries was largely destroyed [5].

The presence of an elite group of leaders of the domestic industry as well as the emergence of several fastgrowing enterprises in Tatarstan indicate the regional growth potential through innovation. Several industrial enterprises of Tatarstan own a large national market share in their respective industries. Most of these companies conducting R\&D 
develop new products and use modern technology.

\section{Results}

There are 12 enterprises with small growth, but the number of employees, during the period 2008-2011 ranged from 35 to 900 percent. In 2009 the number of employees at the enterprises accounted for less than 50 people. Some enterprises are conducted R\&D. The only restriction is that none of the companies don't export products to economics with high income, such as EU or the USA.

The key reasons are that the most enterprises don't take seriously the importance of the innovation and could hardly find a place for it in their strategies and the lack of financial support of innovation projects.

There are a lot of examples in economic literature which prove that the technology changes and the growth are related processes $[2,4,9,11]$. However more than one thirds of the enterprises to the question how often they introduce new production technologies or significantly upgrade old technologies or products, answered that they did not see the need for it.(Fig.1).

The value of this indicator is higher than in most European countries that participate in the statistical Innovation Survey, conducted by the EU. The results of examination also revealed two factors on which value Tatarstan is anomalous: uncertainty about markets and lack of funding cited as the two most significant barriers to innovation. Because the evaluation data is subjective and is connected with personal feelings of entrepreneurs, it is unclear whether these factors are the real reasons for the limited level of innovation activities; there is still necessity to continue their study $[7,11,12]$

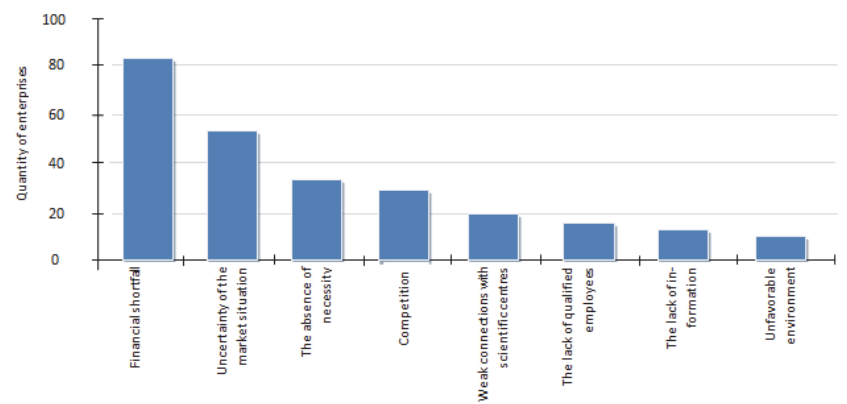

Fig.1 The main factors which restrain innovation in enterprises

As the main reasons of innovation is indicated the lack of funding and high level of competition, which is typical for managers, who do not understand what directions of the market they should invest and in what way to modernize their business.

Figure 2 indicates a passive attitude to competitiveness strengthen.

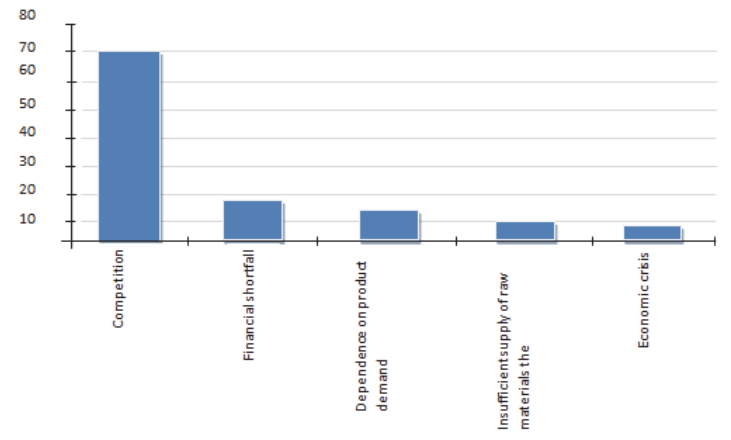

Fig.2. First 5 factors which restrain enterprises growth 
The concept according to which the interaction with the outside world demands too many efforts suggests that entrepreneurs need external support for significant improvements of classical business processes, providing success.

Also they need:

- business information and analytics ;

- a clear assessment of own assets (human capital, efficiency of technologies and so on);

- the possibility of upgrading;

- openness to new products, supply chains and markets.

\section{Conclusions}

Most regions of Russia, one way or another, have paid attention to the development of innovation activity, as reflected in the acts of legislative support for innovations. Most often, these acts are of two types: regional laws on innovation activity and the laws (regulations) on the concepts of innovation development of the region or on programs for support of innovation activity. In general, laws on innovation is a document of explanatory sense, but concepts specify the actions of regional authorities to support innovation activity, which are expressed in creating conditions for innovation activity, in provisioning subsidies and incentives for innovative enterprises and organizations, etc.

A number of federal and regional ministries and agencies, public corporations involved in the formulation and implementation of innovation policy has increased for last $5-6$ years $[3,11]$.

In conclusion, it should be noted that, despite the considerable efforts of Government to stimulate innovation in Tatarstan in this direction serious shortcomings revealed because of all discussed factors which keep from innovation development [8].

1. Weak infrastructure of interaction support between science and research organizations and industry.

2. Lack of support to increase awareness of the industry and markets needs.

3. Lack of incentives for close and systematic cooperation between scientific organizations and industrial enterprises.

4. Lack of tax incentives for research and innovation activity in the industry.

5. Limited promotion of scientific research and innovation projects in industry and promotion of innovative products and services to the markets.

6. Lack of small and medium-sized innovative companies support and innovative projects (growth potential support, help in new connections finding and suppliers etc.).

7. Weak use of advisory services and financial incentives to promote the use of intellectual property rights.

8. Low motivation of young and experienced scientists.

9. Limited support of Tatarstan integration into the international scientific research networks. No conducted activity to attract the best scientists and innovative managers of Tatarstan.

10. Lack of research and development support.

11. Limited support of the manufacturing industry modernization (especially in traditional sectors).

12. Lack of services support in the field of innovation management and consulting.

13. Weak connections support between the basic building blocks of innovation system (state, science, industry, small business innovation).

14. Lack of assessment activities impact (research and innovation) of new draft laws and regulations in any area of policy.

15. Limited investment into the development skills of civil servants in the ministries of innovation sphere.

\section{References}

Panasyuk, M.V., Novenkova, A.Z., Chalova, A.I., Yu Anopchenko, T. Region in the international economic cooperation system // World Applied Sciences Journal, 27(13), 2013, 145-148.

Akhtyamova, N., Azitov, R., Bagautdinova, N.G., Azitova, G. Specifics of management in South-East Asian countries in the light of globalization // World Applied Sciences Journal, 27(13), 2013, 67-71.

Tolmachev, M.N., Bagautdinova, N.G., Yashin, N.S. Differentiation of Russian Region in terms of the agricultural production // World Applied Sciences Journal, 27(13), 2013, 184-188.

Abbey.a and Dickson J.W. (1983) "R \&D" Work climate and innovation in Semiconductors", Academy of Management Journal 26,pp362368.

Background report to the OECD country review of the Russian innovation policy, Moscow, 2009, pp68-88.

Averianov, B.A., Bagautdinova, N.G., Sarkin, A.V. Estimation of manufacturing enterprise development risks in process of operational 
activity // World Applied Sciences Journal, 27(13), 2013, 202-206.

Safiullin L.N., Ismagilova G.N., Safiullin N.Z., Bagautdinova N.G. The development of welfare theory in conditions of changes in the quality of goods and services (2012) World Applied Sciences Journal 18 (Special Issue of Economics), pp. 144-149.

Breschi, S. and F.Lissoni (2001), "Knowledge spillovers and local innovation systems: a critical survey." Industrial and Corporate change 10(4):pp975-1005.

Boschma, R.(2005), "Proximity and Innovation: a critical assessment." Regional studies 39(1): pp.61-74.

Ulesov D.V., Murtazina G., Safiullin L.N. and Saipullaev U.A. Special Aspects of Development of Business in the Knowledge-Based Economy I/World Applied Sciences Journal, 27(13), 2013, pp. 189-192.

Panasyuk, M.V., Safiullin, L.N., Pryadko, I.A., Anopchenko, T.Y. Classification of large and socially important enterprises of the region by the levels of their economic solvency // World Applied Sciences Journal, 27(13), 2013, 140-144.

Carlsson, B. Internationalization of Innovation Systems: A survey of the literature. Research policy,(2006),35(1),pp56-67.

Jensen, M.B., B. Johnson, et al. (2007). "Forms of knowledge and modes of innovation". Research policy 36(5):pp 680-693.

Safiullin, M.R., Elshin, L.A., Prygunova, M.I., Galyavov, A.A. (2013). Complex Analysis of Prospects of the Volga Federal District Regions Development: Methodology and Practice. World Applied Sciences Journal 27, 4, 508-511. 